\title{
Vaccine: New Hope, but It Is Not a Panacea of Pandemic
}

COVID-19 has been a major global health problem. As a pharmaceutical intervention had not yet been available, curbing the spread of COVID-19 has depended on the people's protective behaviors. Although the governments throughout the world encouraged people to wear a face mask, adhere to social distancing, and wash hands using sanitizers, some ignored such a call (Adiyoso \& Wilopo, 2020). Since vaccination has been rolled out to populations near the end of 2020, it instills a new hope for battling against COVID-19. However, the vaccine is not a panacea or end of the pandemic.

COVID-19 vaccine has been available, yet it is limited. Vaccine development is essential, and past experiences have shown that vaccines save millions of lives. The race to find a safe and successful COVID19 vaccine attracted people from all over the world. However, the complexity of COVID-19 virus has made vaccine development incredibly challenging. COVID-19 vaccines are produced to meet high quality, safe, and efficacy requirements as all other vaccines. The effects of COVID-19 vaccines are first tested in the laboratory, including on animals, before tried on human volunteers (WHO, 2021).

According to $\mathrm{WHO}$, at least seven different vaccines have been rolled out in some countries since February 2021 (WHO, 2021). Vaccination is prioritized for vulnerable people in all countries. Vaccines create immunity to minimize the risk of getting a disease. Our body's immune system reacts when we receive a vaccine. Every year, vaccines prevent 2-4 million deaths from diseases such as diphtheria, tetanus, pertussis, influenza, and measles, while around 200 additional vaccine candidates are being developed simultaneously (WHO, 2021). At the same time, a new variant of coronavirus has been discovered (Nikkei staff writers, 2021).

Vaccination is regarded as one of the most effective public health interventions, but some people believe it is dangerous and unwarranted. The concept of risk communication has explained why people neglect to protect themselves from such pandemic by taking the vaccine. Previous studies revealed that protective behavior is determined by complex factors such as demographics, the chance of getting victim, feeling severity, experiences, emotion, self-efficacy, and subjective norm (Dubé et al., 2013). In one place, for example, past experiences are the dominant factor in influencing people to take certain behaviors.

In other populations, variables such as religions, gender, subjective norm, and trust in leadership may affect their behavior to take vaccines. Immunization is an indisputable human right and an essential part of primary health care. It is also one of the most cost-effective health investments (Dubé et al., 2013). Vaccination is one of the best and most effective public health strategies for keeping people healthy. In case of a COVID-19 outbreak, vaccines also will foster social and economic benefits. However, vaccine hesitancy does exist in the community. Understanding the factors that determine vaccine acceptance is crucial. It is needed to trace the historical, political, and socio-cultural contexts. Vaccination decision-

\begin{tabular}{|c|c|c|}
\hline $\begin{array}{l}\text { ARTICLE INFO } \\
\text { Received: March 03, } 2021 \\
\text { Received in revised form: March 03, } \\
2021 \\
\text { Accepted: April 19, } 2021 \\
\text { doi: } 10.46456 / \text { jisdep.v2i1.117 } \\
\text { (C) } 2021 \text { The Author }\end{array}$ & $\begin{array}{l}\text { JISDeP - The Journal of Indonesia } \\
\text { Sustainable Development Planning } \\
\text { Published by Centre for Planners' } \\
\text { Development, Education, and Training } \\
\text { (Pusbindiklatren), } \\
\text { Ministry of National Development } \\
\text { Planning/ National Development } \\
\text { Planning Agency (Bappenas), Republic } \\
\text { of Indonesia }\end{array}$ & $\begin{array}{l}\text { Address: Jalan Proklamasi 70, } \\
\text { Central Jakarta, Indonesia 10320 } \\
\text { Phone: }+622131928280 / 31928285 \\
\text { Fax: }+622131928281 \\
\text { E-mail: } \\
\text { journal.pusbindiklatren@bappenas.go.id } \\
\text { Supported by Indonesian Development Planners } \\
\text { Association (PPPI) }\end{array}$ \\
\hline
\end{tabular}


making should be considered in a wider socio-cultural sense. Vaccination is a part of a broader social world, which means that several factors may contribute to vaccination acceptance.

While the development of vaccines against COVID-19 has continued even for a future pandemic, social behavior-based public health intervention should be promoted for a sustainable public health system. Policymakers should base their decision on evidence-based policymaking. Thus, it is crucial to foster the study preceding the pandemic. Besides, one of the best lessons learned from tackling COVID19 is that cooperation among countries, regions, institutions, government agencies, communities, and individuals is necessary. Scientists from all over the world should work together to save lives and reduce the spreading of coronaviruses.

More efforts to promote vaccine benefits and risks and resolve problems with evidence-based information can help maintain public confidence in vaccines and health systems around the world. Media and social media play important roles in shaping and influencing people regarding public health measures promoted by the government. Measuring and tracking vaccine confidence levels and focusing on deliberate measures to build vaccine credence are critical steps in reducing vaccine reliance discrepancies

As warned by WHO, safe and reliable vaccines would be a game-changer (WHO, 2021), (Wardhana, 2020). We must continue to wear masks, keep a social distancing, and avoid crowds. There is also clear that the degree of effectiveness of the vaccine varies from individual to individual. Being vaccinated does not mean we may be careless and put ourselves and others at high risk. ${ }^{* * *}$

Wignyo Adiyoso, S.Sos., MA., Ph.D.

(Chief of Editor)

\section{References}

Adiyoso, W., \& Wilopo, W. (2020). Social Distancing Intentions to Reduce the Spread of COVID19: The Extended Theory of Planned Behavior. Research Square, Pre-Print.

Dubé, E., Laberge, C., Guay, M., Bramadat, P., Roy, R., \& Bettinger, J. A. (2013). Vaccine Hesitancy an Overview. Human Vaccines \& Immunotherapeutics, 9(8).

Nikkei staff writers. (2021). Japan finds new COVID virus strain, distinct from UK and Africa types. NIKKEI Asia. https://asia.nikkei.com/Spotlight/Coronavirus/Japan-finds-new-COVIDvirus-strain-distinct-from-UK-and-Africa-types

Wardhana, D. (2020). Post-Pandemic Development: Sluggish or Rapid Recovery? The Journal of Indonesia Sustainable Development Planning, 1(3), i-ii.

WHO. (2021). COVID-19 vaccines. WHO. https://www.who.int/emergencies/diseases/novelcoronavirus-2019/covid-19-vaccines 